\title{
Safety and efficacy of dual versus triple antithrombotic therapy in Patients with atrial fibrillation undergoing percutaneous coronary intervention: a meta-analysis
}

Abdelmoniem Moustafa, Mohammad Saud Khan, Abdalla Marei', Mohd Amer Alsamman, Muhammad Baig, Marwan Saad² Department of Internal Medicine, The Miriam Hospital, Warren Alpert School of Medicine at Brown University, Providence, Rhode Island, USA, ${ }^{1}$ Department of Cardiac Surgery, Duesseldorf University Hospital, Düsseldorf, Germany, ${ }^{2}$ Department of Cardiology, Warren Alpert School of Medicine at Brown University, Providence, Rhode Island,USA

\begin{tabular}{|c|}
\hline Access this article online \\
\hline Website: www.avicennajmed.com \\
\hline DOI: 10.4103/ajm.ajm_40_20 \\
\hline Quick Response Code: \\
\hline
\end{tabular}

\begin{abstract}
Background: Patients with atrial fibrillation undergoing percutaneous coronary intervention have indications for oral anticoagulation and dual antiplatelet therapy (DAPT) with aspirin and a P2Y12 receptor inhibitor. The concurrent use of all three agents, termed triple oral antithrombotic therapy (TAT), increases the risk of bleeding. A number of prospective trials showed that the omission of aspirin mitigates the risk of bleeding without affecting major adverse cardiovascular event (MACE). Materials and Methods: The databases of PubMed, Embase, and Cochrane Central databases were searched from inception to October 2019. Relevant randomized control trials comparing dual antithrombotic therapy (DAT) versus TAT were identified and a metanalysis was performed using random-effect model. The safety endpoints of interest were thrombolysis in myocardial infarction criteria (TIMI) major and minor bleeding, TIMI major bleeding, and intracranial bleeding. The efficacy endpoints of interest were MACE and individual components of MACE. Results: Six trials with 11,722 patients were included. For safety endpoint, DAT was associated with significantly lower incidence of TIMI major and minor bleeding [RR: $0.58,95 \% \mathrm{CI} 0.44-0.77, P=0.0001]$, TIMI major bleeding [RR: $0.55,95 \% \mathrm{Cl} 0.42-0.73, P<0.0001$ ] as well as intracranial bleeding [RR: $0.35,95 \% \mathrm{Cl}$ $0.16-0.73, P=0.006]$ compared with TAT. No significant difference was observed for MACE [RR: $0.96(0.79-1.17) P=0.71]$ or any of the individual components of MACE between the two groups. Conclusion: Omission of aspirin from TAT in patients with Atrial Fibrillation (AF) after percutaneous coronary intervention is associated with lower risk of bleeding without compromising the efficacy in terms of mortality and cardiovascular thrombotic events.
\end{abstract}

Key words: Atrial fibrillation, CAD, coronary artery disease, dual antithrombotic therapy, stent, triple antithrombotic therapy

\section{INTRODUCTION}

Coronary artery disease (CAD) occurs in $20 \%-30 \%$ of patients with atrial fibrillation (AF), and $5.3 \%-28 \%$ of hospitalized patients with the acute coronary syndrome (ACS) develop new-onset AF during their hospitalization. ${ }^{[1-3]} \mathrm{AF}$

Address for correspondence: Dr. Abdelmoniem Moustafa, Department of Internal Medicine, The Miriam Hospital, Warren Alpert School of Medicine at Brown University, 164 Summit Ave,

Providence, Rhode Island 02906, USA.

E-mail:mon3melshimi@gmail.com
This is an open access journal, and articles are distributed under the terms of the Creative Commons Attribution-NonCommercial-ShareAlike 4.0 License, which allows others to remix, tweak, and build upon the work non-commercially, as long as appropriate credit is given and the new creations are licensed under the identical terms.

For reprints contact: reprints@medknow.com

Cite this article as: Moustafa A, Khan M, Marei A, Alsamman M, Baig M, Saad M. Safety and efficacy of dual versus triple antithrombotic therapy in Patients with atrial fibrillation undergoing percutaneous coronary intervention: A meta-analysis. Avicenna J Med 2020;10:232-40. 
patients with CHADS2 VASc score of 2 or more who undergo percutaneous coronary intervention (PCI) are candidates for triple antithrombotic therapy (TAT) ${ }^{[4]}$ A combination of an anticoagulant and dual antiplatelet therapy (DAPT) is associated with a high risk of major bleeding 4.7\%-12\% over 12 months. ${ }^{[5-8]}$ The WOEST trial was the first to omit aspirin and compare vitamin $\mathrm{K}$ antagonist (VKA)-based dual antithrombotic therapy (DAT) with clopidogrel versus TAT (VKA, clopidogrel, and aspirin). Results showed statistically significant lower bleeding events without increase in thrombotic events in DAT versus TAT. This opened the gate for further randomized controlled trials (RCT) to compare VKA and non-VKA-based DAT versus TAT. ${ }^{[9]}$ The results were consistently in favor of DAT in terms of lower bleeding events with no difference in efficacy outcome between the two groups. Nevertheless, these studies were not powered to detect the difference in major adverse cardiovascular events (MACE). Although several studies addressed this subject, our meta-analysis included all RCTs that compared VKA and direct oral anticoagulant (DOAC) as part of DAT versus TAT including the recently published ENTRUST AF-PCI trial for edoxaban-based DAT. ${ }^{[10]}$

\section{MATERIALS AND METHODS}

\section{Data sources and search strategy}

This meta-analysis was performed in accordance with the guidelines of the PRISMA (Preferred Reporting Items for Systematic Review and Meta-Analysis). PubMed, Embase, and Cochrane Central databases were searched from inception through October 2019. The following search terms were used: "atrial fibrillation, PCI, percutaneous coronary intervention, dual antithrombotic therapy, and triple antithrombotic therapy." We also manually searched reference lists of retrieved articles to identify any relevant studies. All results were imported into EndNote x8.2 (Clarivate Analytics) and duplicate results were identified and removed.

\section{Study selection/quallity assessment}

Two reviewers (Moustafa A and Khan MS) independently assessed the eligibility of identified studies. A study was considered eligible for inclusion in the analysis if it (1) was a RCT and (2) reported safety and efficacy outcomes comparing DAT and TAT. Only articles published in peer review journals were included. Published abstracts and meeting presentations were excluded. Quality of included studies by assessed by Cochrane risk of bias tool for RCTs. Grades of Recommendation, Assessment, Development and Evaluation (GRADE) tool was then used to assess quality of evidence at each outcome level as recommended by the Cochrane Handbook for Systematic Reviews of Interventions. This tool specifies four levels of quality (high, moderate, low, and very low) depending on the type of studies included in the assessment of each outcome. ${ }^{[11]}$

\section{Data extraction and outcomes definition}

Two authors (Moustafa A and Khan MS) independently extracted data on age, gender, body mass index (BMI), history of hypertension, diabetes mellitus, myocardial infarction, and stroke. The safety endpoints of interest were thrombolysis in myocardial infarction criteria (TIMI) major and minor bleeding, TIMI major bleeding, and intracranial bleeding. The efficacy endpoints of interest were trial defined MACE, all-cause mortality, cardiac mortality, myocardial infarction, ischemic stroke, and stent thrombosis.

\section{Data synthesis and statistical analysis}

Statistical analysis was performed using Review Manager, version 5.3 (Copenhagen: The Nordic Cochrane Centre, The Cochrane Collaboration, 2014). We performed meta-analysis on safety and efficacy outcomes separately. A random-effect model was used to pool data. Subgroup analysis was performed for safety and efficacy outcomes for DOAC-based DAT and TAT. $\mathrm{I}^{2}$ statistic was used to assess heterogeneity among studies. A value of between $25 \%$ and $50 \%$ was considered low heterogeneity, between 50\% and $75 \%$ moderate heterogeneity, and more than $75 \%$ was considered high heterogeneity. Any disagreement among reviewers about study selection, data extraction, or quality assessment was discussed with a third reviewer (Alsamman MA) and resolved with consensus.

\section{RESULTS}

\section{Search results and study population}

PRSIMA flow chart highlights the search strategy [Figure 1 Supplemental Material]. Our initial search strategy yielded 1405 studies; of which six trials were included [Appendix 1 Supplemental Material]. Six randomized control trials with a total of 11,722 patients were included. The trials were conducted in the United States and Europe between 2013 and 2019. Two trials included VKA-based DAT versus TAT. ${ }^{[9,11]}$ The other four trials included DOAC-based DAT versus VKA-based TAT. ${ }^{[10,12-14]}$ History of intracranial bleeding was a common exclusion criterion across the trials. Four trials (DOAC based) excluded patients with mechanical prosthetic valve. Three trials (DOAC based with an exception of ENTRUST AF PCI trial) excluded patients with renal impairment (GFR $<30$ ). In Pioneer-AF PCI, patients with history of ischemic stroke or transient ischemic attack (TIA) were excluded. The majority of population were males (75\%), with age between 69.5 and 73.9 years, with $53 \%$ assigned to DAT and $47 \%$ were included in TAT groups. Patient characteristics are summarized in Table 1, and studies characteristics are shown in Table 2. 


\section{Safety endpoint}

Major bleeding events as per TIMI criteria occurred in 1.7\% of DAT group and 3.2\% of TAT group. DAT group showed significantly lower TIMI minor and major bleeding [7.6\% versus $13.7 \%$, RR $0.58,95 \%$ CI $0.44-0.77, P=0.0001]$, TIMI major bleeding $[1.7 \%$ versus $3.2 \%$ RR $0.55(0.42-0.73)$ $P<0.0001]$, and Intracranial bleeding $[0.25 \%$ versus $0.73 \%$ RR $0.35,95 \%$ CI $0.16-0.73, P=0.006]$ compared with TAT [Figure 1].

\section{Efficacy endpoint}

No significant difference was observed between DAT and TAT groups for endpoints of MACE [8.8\% versus $8.1 \%$, RR $0.96,95 \%$ CI $0.79-1.17, P=0.71]$. Similarly, no difference was identified for other efficacy endpoints including allcause mortality [ $4 . \%$ versus $4.2 \%$, RR $0.9695 \%$ CI $0.71-1.30$, $P=0.78]$, cardiac mortality [2.5\% versus $2.4 \%$, RR 0.98 , 95\% CI $0.70-1.37, P=0.92$ ], MI [3.3\% versus $2.8 \%$, RR $1.14,95 \%$ CI $0.90-1.45, P=0.27]$, Ischemic stroke [0.97\%

\begin{tabular}{|c|c|c|c|c|c|c|}
\hline & $\begin{array}{c}\text { Study } \\
\text { population }\end{array}$ & $\begin{array}{c}\text { Population } \\
\text { no. }\end{array}$ & $\begin{array}{l}\text { Study } \\
\text { type }\end{array}$ & Inclusion criteria & Exclusion criteria & Analysis \\
\hline WOEST 2013 & $\begin{array}{l}\text { Patient taking } \\
\text { anticoagulant } \\
\text { and } \\
\text { undergoing } \\
\mathrm{PCl}\end{array}$ & 573 & $\begin{array}{l}\text { Open label, } \\
\text { multicenter } \\
\text { RCT }\end{array}$ & $\begin{array}{l}\text { Age 18-80 Long-term indication for } \\
\text { oral anticoagulation treatment } \\
\text { Severe coronary lesion with } \\
\text { indication for } \mathrm{PCl}\end{array}$ & $\begin{array}{l}\text { History of intracranial bleeding } \\
\text { Cardiogenic shock } \\
\text { Contraindication to use of aspirin, } \\
\text { clopidogrel, or both } \\
\text { Peptic ulcer in the previous } 6 \text { months } \\
\text { Thrombocytopenia (platelet } \\
\text { concentration lower than } 50 \times 109 / \mathrm{L} \text { ) } \\
\text { TIMI major bleeding in the past } \\
12 \text { months }\end{array}$ & ITT \\
\hline $\begin{array}{l}\text { ISAR TRIPLE } \\
2015\end{array}$ & $\begin{array}{l}\text { Patient taking } \\
\text { anticoagulation } \\
\text { and } \\
\text { undergoing } \\
\mathrm{PCl}\end{array}$ & 614 & $\begin{array}{l}\text { Open label, } \\
\text { multicenter } \\
\text { RCT }\end{array}$ & $\begin{array}{l}\text { Age } \geq 18 \text { years } \\
\text { Patients who have been receiving oral } \\
\text { anticoagulant for at least } 12 \text { months } \\
\text { and receiving a drug-eluting stent for } \\
\text { stable angina or ACS }\end{array}$ & $\begin{array}{l}\text { Previous stent thrombosis, drug-eluting } \\
\text { stent implantation in the left main stem } \\
\text { Active bleeding or bleeding diathesis } \\
\text { History of intracranial bleeding }\end{array}$ & ITT \\
\hline
\end{tabular}

\begin{tabular}{|c|c|c|c|c|c|c|}
\hline PIONEER 2016 & $\begin{array}{l}\text { AF patient } \\
\text { undergoing } \\
\mathrm{PCl}\end{array}$ & 2124 & $\begin{array}{l}\text { Open label, } \\
\text { multicenter } \\
\text { RCT }\end{array}$ & Age $\geq 18$ years & $\begin{array}{l}\text { History of stroke or transient ischemic } \\
\text { attack significant gastrointestinal bleeding } \\
\text { within } 12 \text { months Calculated creatinine } \\
\text { clearance of less than } 30 \mathrm{ml} \text { per minute }\end{array}$ & $\begin{array}{l}\text { ITT and } \\
\text { modified } \\
\text { ITT }\end{array}$ \\
\hline & & & & $\begin{array}{l}\text { AF that occurred within last I year, } \\
\text { or } \mathrm{AF} \text { that occurred more than } \\
\text { I year and the participant had been } \\
\text { receiving oral anticoagulation for } \mathrm{AF} \\
\text { for the last } 3 \text { months }\end{array}$ & $\begin{array}{l}\text { Anemia with a hemoglobin concentration } \\
\text { of less than } 10 \mathrm{~g} \text { per deciliter }\end{array}$ & \\
\hline $\begin{array}{l}\text { RE DUAL PCI } \\
2017\end{array}$ & $\begin{array}{l}\text { Nonvalvular } \\
\text { AF patient } \\
\text { undergoing } \\
\mathrm{PCl}\end{array}$ & 2725 & $\begin{array}{l}\text { Open label, } \\
\text { multicenter } \\
\text { RCT }\end{array}$ & $\begin{array}{l}\text { Age } \geq 18 \text { years } \\
\text { Patients with nonvalvular AF who just } \\
\text { underwent } \mathrm{PCl} \text { with a bare-metal } \\
\text { or drug-eluting stent for ACS or } \\
\text { unstable angina Patients who have } \\
\text { been receiving an oral anticoagulant } \\
\text { or who were treatment-naïve prior } \\
\text { to } \mathrm{PCl}\end{array}$ & $\begin{array}{l}\text { Presence of bioprosthetic } \\
\text { Mechanical heart valves } \\
\text { Creatinine clearance }<30 \mathrm{ml} \text { per minute }\end{array}$ & ITT \\
\hline \multirow[t]{3}{*}{$\begin{array}{l}\text { AUGUSTUS } \\
2019\end{array}$} & $\begin{array}{l}\text { Patient with } \\
\mathrm{AF} \text { and } \mathrm{ACS} \\
\text { and/ or } \mathrm{PCl}\end{array}$ & 4614 & $\begin{array}{l}\text { Open label, } \\
\text { multicenter } \\
\text { RCT }\end{array}$ & Age $\geq 18$ years & $\begin{array}{l}\text { Patients with other conditions that } \\
\text { require anticoagulation (such as prosthetic } \\
\text { valves or moderate or severe mitral } \\
\text { stenosis) }\end{array}$ & $\begin{array}{l}\text { ITT and } \\
\text { modified } \\
\text { ITT }\end{array}$ \\
\hline & & & & $\begin{array}{l}\text { Patients with either active or } \\
\text { a history of AF or flutter with } \\
\text { planned or existing use of an oral } \\
\text { anticoagulant for prophylaxis of } \\
\text { thromboembolism }\end{array}$ & Severe renal insufficiency & \\
\hline & & & & $\begin{array}{l}\text { Patients who have had an ACS and/or } \\
\text { a PCI within the prior } 14 \text { days } \\
\text { Planned use of an approved P2Y } 12 \\
\text { inhibitor for at least } 6 \text { months }\end{array}$ & History of intracranial hemorrhage & \\
\hline $\begin{array}{l}\text { ENTRUST AF PCI } \\
2019\end{array}$ & $\begin{array}{l}\text { AF patient } \\
\text { underwent } \\
\text { successful } \mathrm{PCl}\end{array}$ & 1506 & $\begin{array}{l}\text { Open label, } \\
\text { multicenter } \\
\text { RCT }\end{array}$ & Age $>18$ years & ESRD & ITT \\
\hline
\end{tabular}

$\mathrm{RCT}=$ randomized control trial, $\mathrm{AF}=$ atrial fibrillation, $\mathrm{PCl}=$ percutaneous intervention, $\mathrm{CAD}=$ coronary artery disease, $\mathrm{MS}=$ mitral stenosis, $\mathrm{ACS}=$ acute coronary syndrome, ITT = intention to treat, ESRD = end stage renal disease 
Moustafa, et al:: DAT versus TAT in patients with AF undergoing PCI

\begin{tabular}{|c|c|c|c|c|c|c|}
\hline & WOEST & ISAR triple & $\begin{array}{l}\text { REDUAL- } \\
\text { combined }\end{array}$ & Pioneer & Augustus & Entrust \\
\hline Treatment & DAT $\rightarrow$ TAT & $\mathrm{DAT} \rightarrow \mathrm{TAT}$ & $\mathrm{DAT} \rightarrow \mathrm{TAT}$ & DOAC+P2YI2-TAT & $\mathrm{DOAC}+\mathrm{P} 2 \mathrm{Y} 12$ versus TAT & $\mathrm{DAT} \rightarrow \mathrm{TAT}$ \\
\hline Number & $279 / 284$ & $307 / 307$ & $3039 / 2278$ & $709 / 706$ & $1153 / 1154$ & $751 / 755$ \\
\hline Age & $70.3(7) / 69.5(8)$ & $73.9(7.7) / 73.3(8.7)$ & 70.9/7I.I & $70.4(9.1) / 69.9(8.7)$ & $69.8(9.3) / 70.5(9.07)$ & $69 / 70$ \\
\hline Male & $214 / 234$ & $229 / 242$ & $2279 / 1754$ & $528 / 518$ & $840 / 815$ & $557 / 563$ \\
\hline BMI & $27.5(4.3) / 27.9(4.2)$ & $27.5(4.2) / 27.9(4.6)$ & $27.9 / 28.2$ & $\begin{array}{c}28.6(25.7- \\
32.4) / 29(25.8-32.8)\end{array}$ & & \\
\hline Current smoker\% & $22 / 15$ & $9 / 10$ & $10 / 9$ & $5 / 7$ & & \\
\hline Dyslipidemia\% & $68 / 72$ & $74 / 75$ & $56 / 58$ & $43 / 45$ & & $66 / 64$ \\
\hline Diabetes\% & $24.3 / 25.4$ & $27.7 / 23.5$ & $32 / 32$ & $29 / 31$ & $35.9 / 35.9$ & $34 / 34$ \\
\hline Hypertension \% & $69 / 68$ & $77 / 76$ & $73 / 74$ & $73 / 75$ & $88.8 / 87.8$ & $90 / 91$ \\
\hline History of MI \% & $34 / 35$ & $24 / 29$ & $25 / 26$ & $20 / 22$ & & $25 / 23$ \\
\hline History of heart failure\% & $25.4 / 24.6$ & & & $24 / 24.8$ & $41.9 / 42.5$ & \\
\hline History of stroke\% & $17.6 / 17.6$ & & $7.2 / 10.2$ & & $14.9 / 12.4$ & $13 / 12$ \\
\hline \multicolumn{7}{|l|}{ CHADSVASC } \\
\hline$<3$ & & $4.7 / 7.3$ & $27.4 / 19.7$ & $26.7 / 20.8$ & $21.5 / 20.8$ & \\
\hline$=>3$ & & $95.3 / 92.7$ & $72.6 / 80.3$ & $73.3 / 79.2$ & $78.5 / 79.2$ & \\
\hline \multicolumn{7}{|l|}{ HAS BLED } \\
\hline$<3$ & & & $36.4 / 29.4$ & $27.6 / 29.5$ & $51.7 / 50.9$ & \\
\hline$=>3$ & & & $63.6 / 70.6$ & $72.4 / 70.5$ & 48.3/49.1 & \\
\hline
\end{tabular}

\begin{tabular}{|c|c|c|c|c|c|c|c|c|c|c|c|}
\hline \multirow[b]{2}{*}{ Study or Subgroup } & \multicolumn{2}{|c|}{ DAT } & \multicolumn{2}{|c|}{ TAT } & \multirow[b]{2}{*}{ Weight } & \multicolumn{2}{|l|}{ Risk Ratio } & \multirow{2}{*}{\multicolumn{4}{|c|}{$\begin{array}{c}\text { Risk Ratio } \\
\text { M-H, Random, } 95 \% \mathrm{CI}\end{array}$}} \\
\hline & Events & Total & Events & Total & & $\mathrm{M}-\mathrm{H}$, Random, $95 \% \mathrm{CI}$ & Year & & & & \\
\hline \multicolumn{12}{|c|}{ 1.1.1 TIMI major and minor bleeding } \\
\hline WOEST & 39 & 279 & 89 & 284 & $10.7 \%$ & $0.45[0.32,0.63]$ & 2013 & & $=$ & & \\
\hline ISAR-TRIPLE & 14 & 307 & 15 & 307 & $5.0 \%$ & $0.93[0.46,1.90]$ & 2015 & & - & & \\
\hline PIONEER AF-PCl & 109 & 696 & 167 & 697 & $13.4 \%$ & $0.65[0.53,0.81]$ & 2016 & & - & & \\
\hline RE-DUAL PCI & 56 & 1744 & 69 & 981 & $10.6 \%$ & $0.46[0.32,0.64]$ & 2017 & & $=$ & & \\
\hline AJIGUSTUS & 32 & 1143 & 80 & 1123 & $9.4 \%$ & $0.39[0.26,0.59]$ & 2019 & & 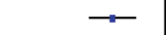 & & \\
\hline $\begin{array}{l}\text { ENTRUST-AF PCI } \\
\text { Subtotal }(95 \% \mathrm{CI})\end{array}$ & 128 & $\begin{array}{r}751 \\
4920\end{array}$ & 150 & $\begin{array}{r}755 \\
4147\end{array}$ & $\begin{array}{l}13.5 \% \\
62.7 \%\end{array}$ & $\begin{array}{l}0.86[0.69,1.06] \\
0.58[0.44,0.77]\end{array}$ & 2019 & & & & \\
\hline Total events & 378 & & 570 & & & & & & & & \\
\hline \multicolumn{12}{|c|}{$\begin{array}{l}\text { Heterogeneity. } \mathrm{Tau}^{2}=0.09 ; \mathrm{Chi}^{2}=22.10, \mathrm{df}=5(\mathrm{P}=0.0005) ;\left.\right|^{2}=77 \% \\
\text { Test for overall effect: } z=3.86(\mathrm{P}=0.0001)\end{array}$} \\
\hline \multicolumn{12}{|c|}{ 1.1.2 TIMI major bleeding } \\
\hline WOET & 9 & 279 & 16 & 284 & $4.2 \%$ & $0.57[0.26,1.27]$ & 2013 & & & & \\
\hline ISAR-TRIPLE & 7 & 307 & 7 & 307 & $2.8 \%$ & $1.00[0.36,2.82]$ & 2015 & & & & \\
\hline PIONEER AF-PCI & 14 & 696 & 20 & 697 & $5.3 \%$ & $0.70[0.36,1.38]$ & 2016 & & - & T & \\
\hline RE-DUAL PCI & 30 & 1744 & 37 & 981 & $8.1 \%$ & $0.46[0.28,0.73]$ & 2017 & & $=-$ & & \\
\hline AUGUSTUS & 13 & 1143 & 29 & 1123 & $5.6 \%$ & $0.44[0.23,0.84]$ & 2019 & & & & \\
\hline $\begin{array}{l}\text { ENTRUST-AF PCI } \\
\text { Subtotal }(95 \% \mathrm{CI})\end{array}$ & 15 & $\begin{array}{r}751 \\
4920\end{array}$ & 24 & $\begin{array}{r}755 \\
4147\end{array}$ & $\begin{array}{r}5.7 \% \\
31.7 \%\end{array}$ & $\begin{array}{l}0.63[0.33,1.19] \\
0.55[0.42,0.73]\end{array}$ & 2019 & & $\longrightarrow$ & & \\
\hline Total events & 88 & & 133 & & & & & & & & \\
\hline \multicolumn{12}{|c|}{$\begin{array}{l}\text { Heterogeneity. Tau }{ }^{2}=0.00 ; \mathrm{Chi}^{2}=3.00, \mathrm{df}=5(\mathrm{P}=0.70) ; \mathrm{I}^{2}=0 \% \\
\text { Test for overall effect: } Z=4.31(\mathrm{P}<0.0001)\end{array}$} \\
\hline \multicolumn{12}{|c|}{ 1.1.3 Intracranial bleeding } \\
\hline WOEST & 1 & 279 & 0 & 284 & $0.3 \%$ & $3.05[0.12,74.64]$ & 2013 & & & & \\
\hline RE-DUAL PCI & 4 & 1744 & 10 & 981 & $2.3 \%$ & $0.23[0.07,0.72]$ & 2017 & & & & \\
\hline AJUGUSTUS & 1 & 1143 & 4 & 1123 & $0.7 \%$ & $0.25[0.03,2.19]$ & 2019 & & & & \\
\hline $\begin{array}{l}\text { ENTRUST-AF PCI } \\
\text { Subtotal }(95 \% \mathrm{CI})\end{array}$ & 4 & $\begin{array}{r}751 \\
3917\end{array}$ & 9 & $\begin{array}{r}755 \\
3143\end{array}$ & $\begin{array}{l}2.3 \% \\
5.6 \%\end{array}$ & $\begin{array}{c}0.45[0.14,1.44] \\
\mathbf{0 . 3 5}[\mathbf{0 . 1 6}, \mathbf{0 . 7 3}]\end{array}$ & 2019 & & & - & \\
\hline \multirow{2}{*}{\multicolumn{12}{|c|}{$\begin{array}{l}\text { Total events } \quad 10 \quad 23 \\
\text { Heterogeneity. Tau }{ }^{2}=0.00 ; \mathrm{Chi}^{2}=2.60, \mathrm{df}=3(\mathrm{P}=0.46) ;\left.\right|^{2}=0 \% \\
\text { Test for owerall effect: } Z=2.77(\mathrm{P}=0.006)\end{array}$}} \\
\hline & & & & & & & & & & & \\
\hline Total $(95 \% \mathrm{Cl})$ & & 13757 & & 11437 & $100.0 \%$ & $0.56[0.46,0.68]$ & & & $\bullet$ & & \\
\hline Total events & 476 & & 726 & & & & & & & & \\
\hline \multicolumn{8}{|c|}{$\begin{array}{l}\text { Heterogeneity. } \mathrm{Tau}^{2}=0.06 ; \mathrm{Chi}^{2}=30.57, \mathrm{df}=15(\mathrm{P}=0.01) ; \mathrm{I}^{2}=51 \% \\
\text { Test for overall effect: } Z=5.95(\mathrm{P}<0.00001) \\
\text { Test for subgroup differences: } C \mathrm{hi}^{2}=1.60, \mathrm{df}=2(\mathrm{P}=0.45), \mathrm{I}^{2}=0 \%\end{array}$} & 0.01 & $\begin{array}{l}0.1 \\
\text { Favours DAT }\end{array}$ & \begin{tabular}{|lr}
1 & 10 \\
Favours TAT
\end{tabular} & $\overrightarrow{100}$ \\
\hline
\end{tabular}

Figure 1: Summary forest plot of safety endpoint in DAT versus TAT groups

versus $1.1 \%$, RR $0.80,95 \%$ CI $0.51-1.26, P=0.34]$, or stent thrombosis [1.4\% versus 1.1. RR 1.32, 95\% CI 0.88-1.96, $P=0.18$ ] [Figure 2].
DOAC-based DAT versus TAT

Subgroup analysis was conducted by including only DOAC-based DAT versus TAT after excluding the 
WOEST and ISAR TRIPLE trials. Compared with TAT, DOAC-based DAT remained associated with significantly lower TIMI major and minor bleeding $[7.4 \%$ versus $13.1 \%$ RR $0.58(0.42-0.81) P=0.001]$, TIMI major bleeding [1.6\% versus $3 \%$ RR $0.53(0.39-0.71)$ $P<0.0001]$, and intracranial bleed $[0.24 \%$ versus $0.8 \%$ RR $0.31(0.14-0.66) P=0.003]$ compared with TAT [Figure 3].

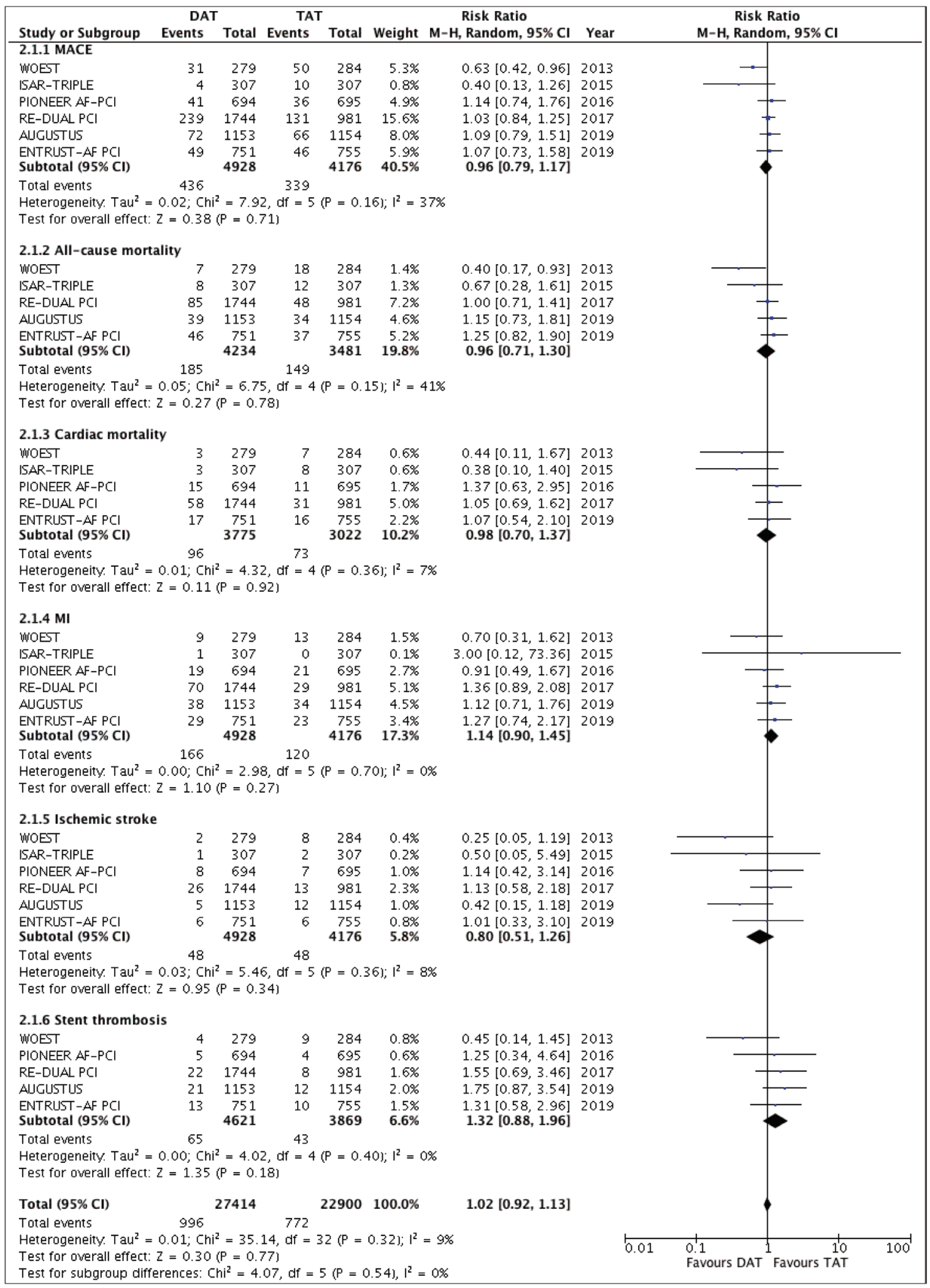

Figure 2: Summary forest plot of efficacy endpoint in DAT versus TAT groups 
Moustafa, et al.: DAT versus TAT in patients with AF undergoing PCI

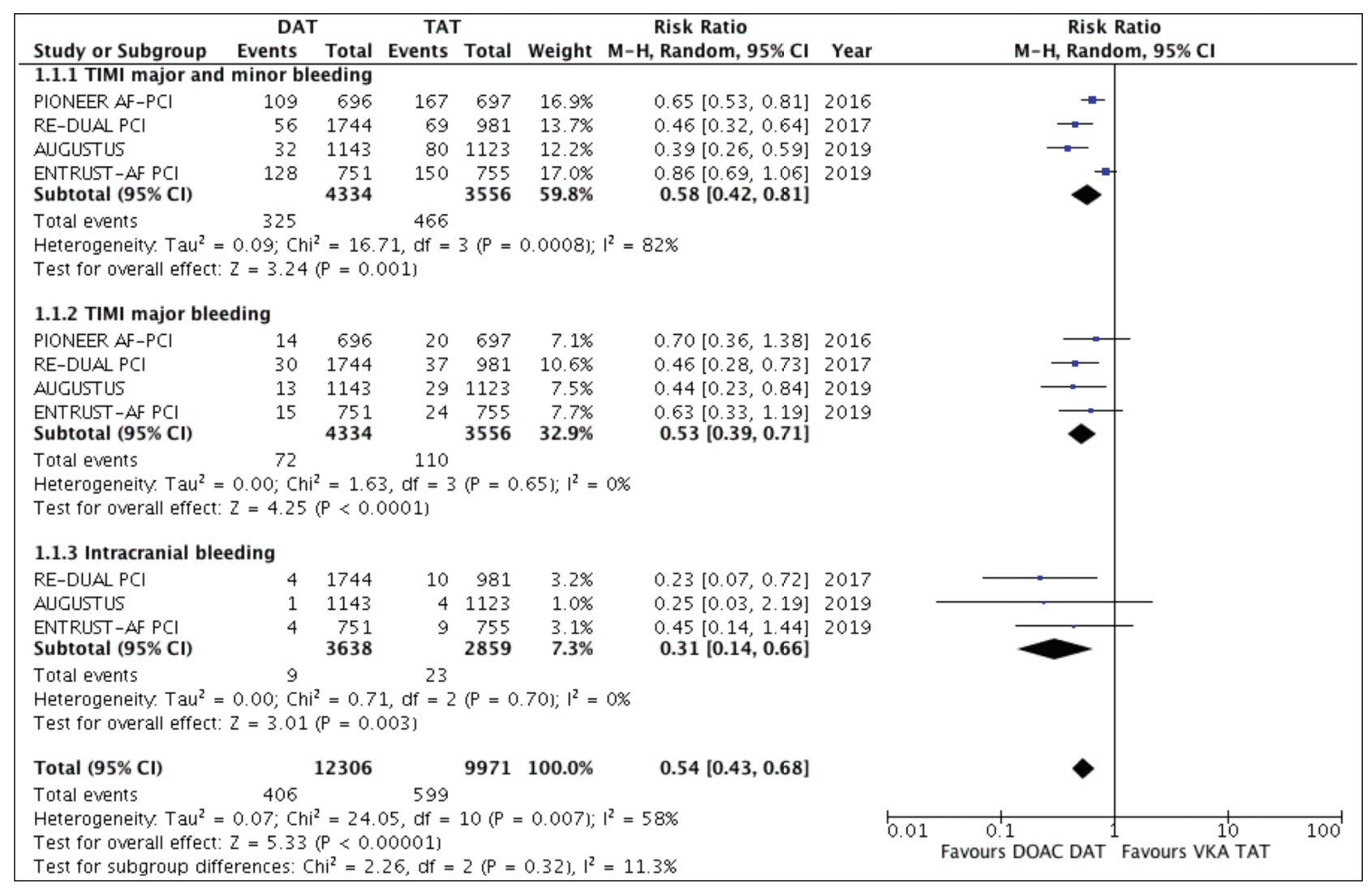

Figure 3: Summary forest plot of safety endpoint in DOAC-based DAT versus TAT groups—sensitivity analysis

On the contrary, no difference was observed between DAT and TAT in terms of composite of MACE (9.2\% versus $7.8 \%$ RR 1.06 95\% CI (0.91-1.22) $P=0.45]$, all-cause mortality [4.7\%-4.1\% RR $1.1195 \%$ CI $(0.88-1.39) P=0.39$ ], cardiac mortality [2.8\% versus $2.4 \%$ RR $1.1195 \%$ CI $(0.80-1.54)$ $P=0.54]$, MI [3.6\% versus 3\% RR $1.1895 \%$ CI $(0.93-1.52)$ $P=0.18$ ], or ischemic stroke [1\% versus $1 \%$ RR $0.9295 \%$ CI (0.59-1.44) $P=0.72]$. Higher rate of stent thrombosis was found in DOAC-based DAT versus TAT but did not reach statistical significance [1.4 versus $0.9 \% 1.5195 \% \mathrm{CI}$ (0.99-2.31) $P=0.05$ ] [Figure 4].

\section{Quality assessment and risk of bias}

All trials reported random sequence generation, and concealment of allocation. Hence, the selection bias was deemed low in all the trials. Although all the trials had openlabel study design, outcome assessment was performed by independent committees whose members were unaware of the patient's treatment assignment. Therefore, the studies design did not influence reported outcomes. Hence, the risk of detection and performance bias were considered low in all of them. Moreover, attrition and reporting bias were deemed low in all trials. Overall risk of bias was deemed low in all the trials [Table 1 Supplemental Material]. Body of evidence for the outcomes reached the level of high quality according to the Grades of Recommendation, Assessment,
Development and Evaluation too [Table 2 Supplemental Material]. Publication bias was assessed by visual inspection of funnel plots [Figures 2 and 3 Supplemental Material].

\section{DISCUSSION}

In our meta-analysis we found that DAT was associated with reduction in bleeding events without significant difference in adverse cardiovascular events compared with TAT. First, omission of aspirin resulted in $42 \%$ relative risk reduction in TIMI major or minor bleeding, as well as 65\% relative risk reduction in incidence of intracranial bleeding with DAT versus TAT. After excluding WOEST and ISAR TRIPLE trials, analysis of the 4 trials with DOAC-based DAT versus VKA based TAT (PIONEER AF, PCI- REDUAL PCI, AUGUSTUS and ENTRUST-AF PCI) re-demonstrated the significant reduction of TIMI major or minor bleeding and intracranial bleeding. ${ }^{[9,10,12-15]}$ Majority of study population in DOAC-based DAT trials had HAS BLED score $>=3$ and were at high risk of bleeding. HAS BLED score was not implemented in WOEST and ISAR TRIPLE trials. Landmark analysis of ISAR TRIPLE trial did not show a significant reduction in bleeding events between 6 weeks to 6 months in VKA based DAT and TAT. However, short follow up period is one of the drawbacks of this study. ${ }^{[1]}$ As of shown in a meta-analysis bleeding events could increase 


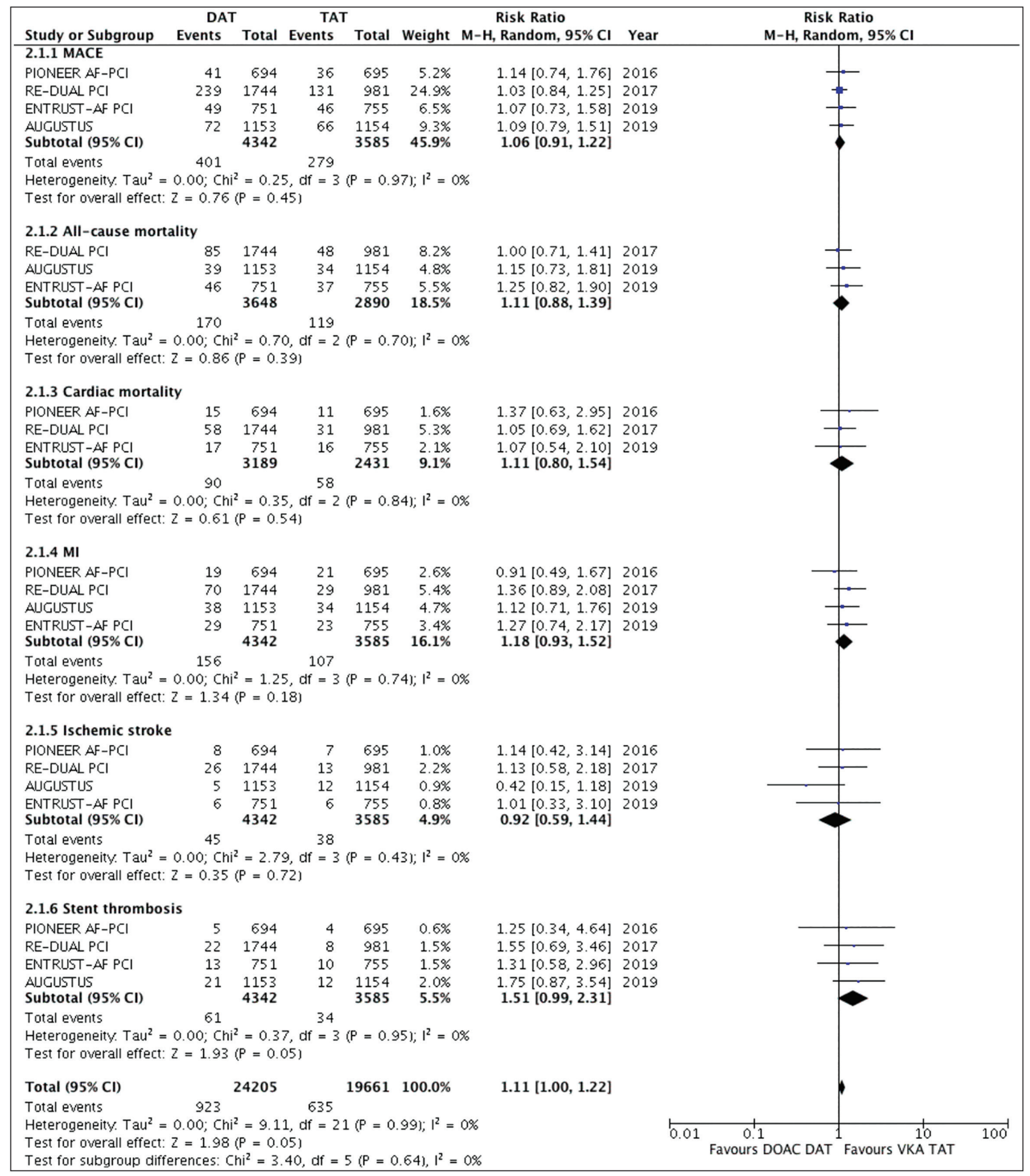

Figure 4: Summary forest plot of efficacy endpoint in DOAC-based DAT versus TAT groups-sensitivity analysis

by 6 folds by end of 12 month use of TAT. ${ }^{[8]}$ Also, the trial was powered to detect any difference between shorter (6 weeks) and longer (6 months) of TAT treatment, and the results came in favor of shorter TAT duration that was not associated with increase in ischemic adverse cardiovascular events.
Second, although each individual trial showed no difference in composite or individual component MACE between the two groups, skepticism about the validity of the results arose as trials were not powered to detect differences in ischemic events. In our analysis of 11722 subjects, no significant difference in composite nor individual component of MACE 
was observed between DAT and TAT groups. Nevertheless, Subgroup analysis including only DOAC-based DAT versus TAT showed tendency for higher stent thrombosis events in DAT versus TAT.

REDUAL PCI, PIONEER and AUGUSTUS population tended to have lower CHADS VASc scores, whereas ENTRUST AF-PCI and ISAR TRIPLE had higher average CHADS VASc score as shown in Table 2. ${ }^{[9,10,12-15]}$ In PIONEER AF PCI trial, patients with prior history of stroke or TIA were excluded. Moreover, patients with GFR $<30$ were excluded from 3 trials (REDUAL PCI, PIONEER, and AUGUSTUS). ${ }^{[9,10,12-15]}$ We did not include rivaroxaban 2.5 plus DAPT group in PIONEER trial as efficacy of rivaroxaban small dose 2.5 to prevent ischemic stroke was not tested before. ${ }^{[9,10,12-15]}$ In REDUAl PCI, study only combined results of dabigatran $110 \mathrm{mg}$ and $150 \mathrm{mg}$ were included in the analysis. ${ }^{[9,10,12-15]}$

DAPT for one year is the standard of care for all patients with ACS whether the patient has undergone stent placement or is being treated medically. ${ }^{[3,16-18]}$ However, DAPT alone has failed to provide stroke prevention in AF population (annual risk of stroke with DAPT versus oral anticoagulant (OAC) was $5.60 \%$ versus $3.93 \%$, with a relative risk of $1.44,95 \%$ CI 1.18-1.76; $P=0.0003) .{ }^{[19]}$ Adding VKA to DAPT in AF population with CAD resulted in $4.7 \%-6.6 \%$ major bleeding risk which commonly occur in the first month. ${ }^{[3,5,7,20]}$ The risk of major bleeding continues to rise to up to $12 \%$ by the end of 12 months. ${ }^{[8]}$ In our analysis, annual risk for bleeding in patient on TAT was $6.3 \%$. The WOEST trial opened the gate for the possibility of dropping aspirin from TAT, with the result of a significant reduction of both bleeding and ischemic event. Lower MACCE events in DAT arm of WOEST trial can be explained with higher chance of DAPT interruption in TAT group as a result of more frequent bleeding events. ${ }^{[9,10,12-15]}$ Indeed, all trials that compared DAT versus TAT showed a significant reduction in bleeding events with ISAR TRIPLE trial as an exception that showed no difference between 2 groups in landmark analysis. Our meta-analysis expanded to include the most recent evidence and our results came in line with the results of other metaanalysis. ${ }^{[21,22]}$ Moreover, our analysis showed statistically significant lower intracranial bleed in favor of DAT group. A 50\% increase in stent thrombosis in DOAC-based DAT versus TAT was an interesting finding in our analysis that included only DOAC-based DAT with $P=0.05$. Further studies are needed to assess the significance of this finding.

According to the American Heart Association guidelines for AF that were published in 2014 and an update in 2019, it may be reasonable to use clopidogrel in combination with oral anticoagulants (without specifying a particular anticoagulant) without aspirin after coronary revascularization. ${ }^{[23,24]}$ On the contrary, the ESC 2016 guidelines adopted a shorter period of TAT of 1 month followed by dual therapy (OAC plus a single antiplatelet). ${ }^{[25]}$

Data are scarce when it comes to other P2Y12 inhibitors impact as a part of DAT or TAT on bleeding and efficacy endpoints. In Re-Dual PCI trial, subgroup analysis showed a $15 \%-50 \%$ increase in bleeding event rate in patients who had taken ticagrelor as part of TT with VKA or DT with dabigatran versus. other P12Y2 inhibitors. Similar results were observed in AUGUSTUS trial where higher bleeding rate was found in patients who had received prasugrel and ticagrelor versus. clopidogrel. ${ }^{[3,13,15]}$

The results of the ongoing prospective MANJUSRI trial are eagerly awaited, as it would provide data on the better combination therapy (ticagrelor and warfarin versus. aspirin, clopidogrel, and warfarin) for patients with $\mathrm{AF}$ and CAD. ${ }^{[26]}$

\section{CONCLUSION}

In patient with AF after PCI, VKA or non-VKA-based DAT after omission of aspirin is as effective as TAT in preventing adverse cardiovascular events but with a significantly lower bleeding risk including major bleeding and intracranial hemorrhage. Tendency for higher stent thrombosis was found in DOAC-based DAT but did not reach statistical significance.

\section{Financial support and sponsorship Nil.}

\section{Conflicts of interest}

There are no conflicts of interest.

\section{REFERENCES}

1. Nieuwlaat R, Capucci A, Camm AJ, Olsson SB, Andresen D, Davies DW, et al.; European Heart Survey Investigators. Atrial fibrillation management: A prospective survey in ESC member countries: The euro heart survey on atrial fibrillation. Eur Heart J 2005;26: 2422-34.

2. Nabauer M, Gerth A, Limbourg T, Schneider S, Oeff M, Kirchhof P, et al. The registry of the German competence network on atrial fibrillation: Patient characteristics and initial management. Europace 2009;11:42334.

3. Moustafa A, Ruzieh M, Eltahawy E, Karim S. Antithrombotic therapy in patients with atrial fibrillation and coronary artery disease. Avicenna J Med 2019;9:123-8.

4. January CT, Wann LS, Calkins H, Chen LY, Cigarroa JE, Cleveland JC Jr, et al. 2019 AHA/ACC/HRS focused update of the 2014 AHA/ACC/ HRS guideline for the management of patients with atrial fibrillation: A report of the American College of Cardiology/American Heart Association task force on clinical practice guidelines and the heart 
rhythm society in collaboration with the society of thoracic surgeons. Circulation 2019;140:e125-51.

5. Khurram Z, Chou E, Minutello R, Bergman G, Parikh M, Naidu S, et al. Combination therapy with aspirin, clopidogrel and warfarin following coronary stenting is associated with a significant risk of bleeding. J Invasive Cardiol 2006;18:162-4.

6. Waldo AL. Clopidogrel plus aspirin versus oral anticoagulation for atrial fibrillation in the Atrial fibrillation Clopidogrel Trial with Irbesartan for prevention of Vascular Events (ACTIVE W): A randomised controlled trial. In: Yearbook of Cardiology; 2007. p. 423-4.

7. Asencio LA, Huang JJ, Alpert JS. Combining antiplatelet and antithrombotic therapy (triple therapy): What are the risks and benefits? Am J Med 2014;127:579-85.

8. Faxon DP, Eikelboom JW, Berger PB, Holmes DR, Bhatt DL, Moliterno DJ, et al. Antithrombotic therapy in patients with atrial fibrillation undergoing coronary stenting. Circ Cardiovas Interv 2011;4:522-34.

9. Dewilde WJM, Oirbans T, Verheugt FWA, Kelder JC, De Smet BJ, Herrman J-P, et al. Use of clopidogrel with or without aspirin in patients taking oral anticoagulant therapy and undergoing percutaneous coronary intervention: An open-label, randomised, controlled trial. Lancet 2013;381:1107-15.

10. Vranckx P, Valgimigli M, Eckardt L, Tijssen J, Lewalter T, Gargiulo G, et al. Edoxaban-based versus vitamin $\mathrm{K}$ antagonist-based antithrombotic regimen after successful coronary stenting in patients with atrial fibrillation (ENTRUST-AF PCI): A randomised, open-label, phase 3b trial. Lancet 2019;394:1335-43.

11. Atkins D, Best D, Briss PA, Eccles M, Falck-Ytter Y, Flottorp S, et al.; GRADE Working Group. Grading quality of evidence and strength of recommendations. BMJ 2004;328:1490.

12. Fiedler KA, Maeng M, Mehilli J, Schulz-Schüpke S, Byrne RA, Sibbing D, et al. Duration of triple therapy in patients requiring oral anticoagulation after drug-eluting stent implantation: The ISAR-TRIPLE trial. J Am Coll Cardiol 2015;65:1619-29.

13. Cannon CP, Bhatt DL, Oldgren J, Lip GYH, Ellis SG, Kimura T, et al.; REDUAL PCI Steering Committee and Investigators. Dual antithrombotic therapy with dabigatran after $\mathrm{PCl}$ in atrial fibrillation. $\mathrm{N}$ Engl J Med 2017;377:1513-24.

14. Gibson CM, Mehran R, Bode C, Halperin J, Verheugt FW, Wildgoose P, et al. Prevention of bleeding in patients with atrial fibrillation undergoing PCI. N Engl J Med 2016;375:2423-34.

15. Lopes RD, Heizer G, Aronson R, Vora AN, Massaro T, Mehran R, et al.; AUGUSTUS Investigators. Antithrombotic therapy after acute coronary syndrome or PCI in atrial fibrillation. N Engl J Med 2019;380: 1509-24.

16. Yusuf S, Zhao F, Mehta SR, Chrolavicius S, Tognoni G, Fox KK. Effects of clopidogrel in addition to aspirin in patients with acute coronary syndromes without ST-segment elevation. N Engl J Med 2001;345(7):494-502 [erratum appears in N Engl J Med 2001 Dec 6;345(23):1716; Nov 15;345(20):1506].

17. Wijns W, Kolh P, Danchin N, Mario CD, Falk V, Folliguet T; European Association for Percutaneous Cardiovascular Interventions EA. The task force on myocardial revascularization of the European Society of Cardiology (ESC) and the European Association for Cardio-Thoracic Surgery (EACTS). Eur Heart J2010;31:2501-55.

18. Amsterdam EA, Wenger NK, Brindis RG, Casey DE Jr, Ganiats TG, Holmes DR Jr, et al.; ACC/AHA Task Force Members; Society for Cardiovascular Angiography and Interventions and the Society of Thoracic Surgeons. 2014 AHA/ACC guideline for the management of patients with non-ST-elevation acute coronary syndromes: Executive summary: A report of the American College of Cardiology/American Heart Association task force on practice guidelines. Circulation 2014;130:2354-94.

19. Connolly S, Pogue J, Hart R, Pfeffer M, Hohnloser S, Chrolavicius S; ACTIVE Writing Group of the ACTIVE Investigators. Clopidogrel plus aspirin versus oral anticoagulation for atrial fibrillation in the Atrial fibrillation Clopidogrel Trial with Irbesartan for prevention of Vascular Events (ACTIVE W): A randomised controlled trial. Lancet 2006;367:1903-12.

20. Rogacka R, Chieffo A, Michev I, Airoldi F, Latib A, Cosgrave J, et al. Dual antiplatelet therapy after percutaneous coronary intervention with stent implantation in patients taking chronic oral anticoagulation. JACC Cardiovasc Interv 2008;1:56-61.

21. Golwala HB, Cannon CP, Steg PG, Doros G, Qamar A, Ellis SG, et al. Safety and efficacy of dual versus. Triple antithrombotic therapy in patients with atrial fibrillation following percutaneous coronary intervention: A systematic review and meta-analysis of randomized clinical trials. Eur Heart J 2018;39:1726-35a.

22. Lopes RD, Hong H, Harskamp RE, Bhatt DL, Mehran R, Cannon CP, et al. Safety and efficacy of antithrombotic strategies in patients with atrial fibrillation undergoing percutaneous coronary intervention: A network meta-analysis of randomized controlled trials. JAMA Cardiol 2019;4:747-55.

23. Nishimura RA, Otto CM, Bonow RO, Carabello BA, Erwin JP 3rd, Guyton RA, et al.; American College of Cardiology/American Heart Association Task Force on Practice Guidelines. 2014 AHA/ACC guideline for the management of patients with valvular heart disease: A report of the American College of Cardiology/American Heart Association task force on practice guidelines. J Am Coll Cardiol 2014;63:e57-185.

24. January CT, Wann LS, Calkins H, Chen LY, Cigarroa JE, Cleveland JC Jr, et al. 2019 AHA/ACC/HRS focused update of the 2014 AHA/ACC/ HRS guideline for the management of patients with atrial fibrillation: A report of the American College of Cardiology/American Heart Association task force on clinical practice guidelines and the heart rhythm society. J Am Coll Cardiol 2019;74:104-32.

25. Kirchhof P, Benussi S, Kotecha D, Ahlsson A, Atar D, Casadei B, et al. 2016 ESC guidelines for the management of atrial fibrillation developed in collaboration with EACTS. Rev Esp Cardiol (Engl Ed) 2017;70:50.

26. Lu W, Chen L, Wang Y, Yao Y, Fu C, Zuo P, et al. Rationale and design of MANJUSRI trial: A randomized, open-label, active-controlled multicenter study to evaluate the safety of combined therapy with ticagrelor and warfarin in AF subjects after PCl-eS. Contemp Clin Trials 2015;40:166-71. 